\title{
“LA LUJURIA ES UN MONUMENTO SECRETO”: CUERPOS Y EROS EN ALDA MERINI
}

\author{
Mercedes Arriaga Flórez \\ Universidad de Sevilla
}

\begin{abstract}
The body with regard to love-eros in Alda Merini follows, in part, the philosophic tradition of authors like Baille, Lévinas, Sartre, Blanchot or Barthes but, in part, it moves away as it takes as the basis of its poetics a female body with all its biologic, semiotic and symbolic involvements. In the last four years' poetry, we attend a contradictory representation of female body that follows images of patriarchal culture and, at the same time, images that refer to the symbolic order of the Mother. The latter inserts itself in the text through metaphors related to the female body (the son-lover, maternity, virginity, and so on), gives visibility to figures proscribed in literature, like "the old woman", and leads writing to an obscene holiness zone, in which the female becomes "incarnate" in grotesque representations and identifies with the nature forces. The representation of desire and female body puts up with a rewriting of masculinity, which becomes "otherness" and, at the same time, reaches the status of utopian and imaginary representation.
\end{abstract}

Señala Umberto Galimberti que "la experiencia de nuestra corporeidad no es la experiencia de un objeto, sino de nuestra manera de habitar el mundo" (Galimberti 2002: 321). En ese sentido, todos los cuerpos están encarnados, ocupan posiciones espaciotemporales y mantienen relaciones de subalternidad o de dominio en lo social, pero también son cuerpos imaginados y codificados en la tradición cultural. Mariella Pandolfi, recogiendo una corriente de pensamiento en la que se encuentran Foucault (1987) y Bourdieu (2000), señala la imposibilidad de separar el cuerpo del sujeto que lo encarna y, al mismo tiempo, del cuerpo social del que forma parte (Pandolfi 1996: 21). De estas consideraciones podemos concluir, entonces, que la posición, consideración y percepción del cuerpo masculino es muy diferente de la del cuerpo femenino.

Jaime Gil de Biedma afirma que el cuerpo es "el mejor amigo del hombre" (AA.VV. 1999: 7). Sin embargo Roland Barthes nutre algunas dudas sobre esta "amistad", detectando un considerable margen de desacuerdo: "de hecho, mi cuerpo no siempre tiene mis mismas ideas" (Barthes 1975: 17). Juan Ramón Jiménez, citando las palabras que Shakespeare pone en boca del Rey Lear, nos ofrece una definición-visión del cuerpo femenino muy difundida en nuestra cultura:

Verdaderamente es difícil concebir nada más bello, más perfecto, más gracioso, que la mujer bella de cintura para arriba, con sus ojos, su frente, su corazón. De cintura arriba son 
la madre, la hermana, la hija, la amiga. Difícil es concebir cosa más fea, más sosa, más perfectamente baja, que la mujer bella de cintura abajo, con la ceguera impersonal de su sexo, tan lejano a su frente. De cintura para abajo son la prostituta, la querida. La esposa es el difícil, el imposible equilibrio (Jiménez 1967: 45).

La división de la anatomía femenina en dos cuerpos irreconciliables responde, al mismo tiempo, al "valor de uso" y al "valor de intercambio" que ésta adquiere en su relación con los varones. Una ambigüedad que se refleja en la contradictoria colocación en nuestra cultura: el cuerpo femenino es símbolo del bien y del mal, de la belleza ideal y la fealdad más despreciable, de la vida y de la muerte.

La mujer de carne y hueso es una paradoja en la que se enfrentan el "Leib", cuerpo viviente, y el "körper", cuerpo orgánico. Una contradicción entre "ser un cuerpo" y "poseer un cuerpo" que, muchas veces, naufraga en la imposibilidad, como señalaba Juan Ramón Jiménez, y en el rechazo, en un cortocircuito entre el cuerpo de carne y su representación en lo simbólico (Arriaga 2003: 409-417). El cuerpo de la mujer, que ha sido representado y codificado por hombres dentro de la literatura, y las artes en general, lucha en las escritoras por buscar definiciones y representaciones de sí que no sean las del patriarcado, y en este sentido su lenguaje es sólo un proyecto. Como señala Humberto Galimberti, nuestra cultura no permite a la mujer expresar su "cuerpo natural", es decir, su sexualidad y, por otra parte, su "cuerpo social" le es extraño, al ser propiedad de los hombres (Galimberti 2000: 430).

La reciente producción poética de Alda Merini se desarrolla en torno a ese proyecto en el que el cuerpo de mujer intenta redefinirse y recolocarse, atravesando diferentes y contradictorias nociones de cuerpo, asociado muchas veces al eros-amor, como indican las antologías de los últimos cuatro años: "El alma enamorada" (2000), "Palabras de amor. Un encuentro con Jesús" (2001), "Loca, loca, loca de amor por ti" (2002), "Clínica del abandono" y "La carne de los ángeles" (2003). El rasgo más vistoso de estos títulos es la indeterminación y evanescencia de conceptos como "alma" y "cuerpo", que pierden sus fronteras recíprocas. Se trata de un alma, al mismo tiempo mortal e inmortal, y de un cuerpo simultáneamente físico y espiritual, material y trascendental, entre los que no existe separación sino fusión, a través del encuentro con quien se ama:

El amor santifica el alma y le implora que no lo deje, porque el amor subyace a un deseo del cuerpo tan profundo que el alma quisiera marcharse para gozar espacios menos fragmentarios, pero también es verdad que el alma en el amor conoce la primera ocasión de meditar sobre los males del cuerpo y, por lo tanto, curiosamente también adquiere una conciencia física (Merini 2000: 83-84) ${ }^{1}$.

El eros-amor, que en nuestra cultura poseen una historia en común marcada por la ambigüedad de sus fronteras y, a veces, por su radical oposición, tiende un puente entre el alma encarnada y el cuerpo espiritualizado. El sentimiento de "profunda continuidad" (Bataille 1991: 17), es precisamente la función que Bataille atribuye al erotismo. Paralelamente Alda Merini coloca el erotismo en una dimensión religiosa (Bataille 1991:

\footnotetext{
'Este pasaje y los siguientes citados, tanto en prosa como en verso, de Alda Merini son inéditos en lengua castellana. La traducción es mía (N.de la A.).
} 
31), que presupone, al mismo tiempo, una experiencia exterior e interior, y donde el contacto físico posee una significación litúrgica, ritual, relacionada siempre con la palabra.

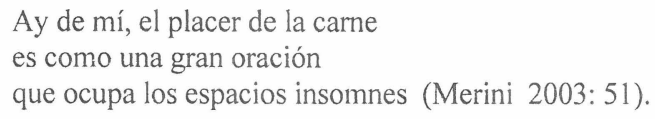

El amor-erotismo funde corporeidad y espiritualidad en un mismo acto. De hecho Bataille distingue tres tipos de erotismo, "de los cuerpos, de los corazones y sagrado" (Bataille 1991: 17), que en la poética de Alda Merini componen una "trinidad" indivisible:

El número tres aparece muchas veces en la Divina Comedia y también yo hablo de ello en la Tierra Santa, hablo de una triada de dioses, que son carne, espíritu y materia" (Merini 2000: 28).

La síntesis que se realiza a través del erotismo es paralela a la síntesis de la poesía, capaz de conectar realidades distantes en la dimensión de la memoria, del sueño, del deseo, de la fantasía. Como ya señalaban los padres de la Iglesia: "Imaginar significa consentir (consensio) las imágenes que demoran vivas en la memoria para que se cumpla un placer (delectatio) y casi un hecho (factum simillimum)" (Sissa 1996: 105). En ese contexto, "hacer el amor" va más allá de ser un hecho corporal, para simbolizar una profunda comunicación, en la que la unión carnal simboliza una fusión "superior", concretamente, una unión trascendental en la palabra, es decir, una "comunión" de poetas, pero también es expresión de la libido de la mujer, que según Hèlène Cixous (1997: 239), es "cósmica" y, por lo tanto, capaz de atravesar y conectar distancias insuperables. En la misma línea Pinkola Estés subraya que la sexualidad de la mujer es una expresión sagrada que consiste en "una conciencia sensorial que incluye la sexualidad, pero no se limita a ésta" (Pinkola 2001: 541).

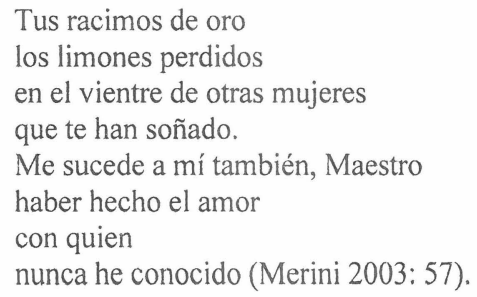

Como señala Umberto Galimberti, en esta circuntancia el cuerpo se hace objeto de deseo "no sólo en su carne inmediatamente presente, sino porque en su carne se manifiesta una vida y un ofrecimiento a participar en ella" (Galimberti 1995: 137). Bataille, Sartre (1965), y el mismo Galimberti, hacen hincapié en esta dimensión del eros que pertenece a la esfera de lo imaginario, como efecto producido por el lenguaje y la escritura. Una dimensión que no se le escapa tampoco a Alda Merini, cuando habla de los enamorados como "purísimos simulacros" (Merini 1994: 69).

Ya Platón señalaba que eros es, al mismo tiempo, filósofo, político y lenguaje. Por lo tanto, de la misma forma que la carne se hace espíritu, también se trasforma en palabra: el erotismo de los cuerpos se traduce en el erotismo de la palabra. Como sostiene Roland 
Barthes, la escritura es la "ciencia de los placeres del lenguaje, su kamasutra" (Barthes 1975: 6).

No soy una mujer de amor, a pesar de que soy muy apasionada y atribuyo este exceso mío más bien al gusto sádico de la palabra que al gusto angélico de la carne (Merini 1994: 70).

Recuerdo el periodo de la adolescencia, cuando la curiosidad por el sexo se convertía en curiosidad por la palabra (Merini 2003a: 35).

Por otra parte, la escritura que alimenta la pasión, y la pasión que alimenta la escritura es un tema constante en la poesía, no sólo italiana. Gaspara Stampa escribía: "mi sento il cor di nuovo stile impreso" (Stampa 1954: 86), señalando la pasión como el motor fundamental de su creación poética.

La palabra poética, que "conecta divino y humano, incorpora carne y pensamiento, mujer y búsqueda de la salvación en la palabra" (Merini 1994: 7), es paralela al eros que conecta pecado y redención, carne y espiritualidad, prohibición y trasgresión, pero también es una palabra a la que la mujer tiene acceso desde la antiguedad, mientras que, por su condicion de "materia", no ha podido elevarse a otro tipo de "logos" superior (de la autoridad, de la ciencia, etc.). La mujer, como la poesía, ocupa el lugar del anti-logos, el lugar donde el lenguaje escapa a sus rígidas reglas, el lugar del "instinto", el lugar semiótico (Kristeva 2000) que pertenece al orden materno.

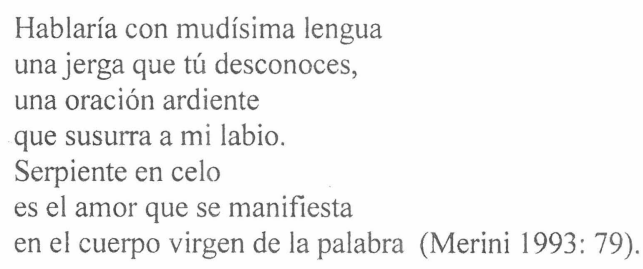

La "mudísima lengua", la "jerga desconocida", "la oración ardiente", "el cuerpo virgen de la palabra", son las metáforas en las que se cifra la imposibilidad de "decir", de "nombrar" el deseo y el eros en femenino. Deseo y eros que Alda Merini identifica con la experiencia límite de la poesía: intermediaria entre la muda realidad y su recreación en sonidos, entre lo visible y lo que permanece oculto, entre el presente que se vive y el futuro que se sueña. La poesía, entonces, no difiere mucho de la condición femenina que aparece en la seducción, según Baudrillard, Lévinas, Bataille y otros: rostro que se da, materialidad inmediata en la carne, epifanía, y al mismo tiempo, diseminación anárquica que permanece fuera del orden de la verdad y del sentido.

El misterio de la "palabra poética", que Alda Merini identifica muchas veces con la "palabra profética", pertenece a la mujer porque proviene de su naturaleza salvaje, de su fuerza "Vida/Muerte/Vida" (Pinkola 2001: 27):

Te gustaba la flor de mi palabra, la lengua secreta que ningún hijo nunca conoció ni siquiera en el momento de su concepción

(Merini 2003a: 112) 
La Madre es la depositaria de esa "lengua secreta", relacionada con su capacidad de creación y reproducción. Alda Merini reúne las imágenes del mito pagano de la Mujer Salvaje (Pinkola 2001), remitiéndose al orden simbólico de la madre (Muraro 1991), en contraposición, y a veces superposición, con el orden simbólico patriarcal. Un ejemplo de ello es cómo Alda Merini trasforma la correspondencia abstracta entre eros y poesía de Bataille, encarnando el concepto "poesía" en el cuerpo de los poetas, crisol donde se fragua la palabra poética, que es una palabra de amor.

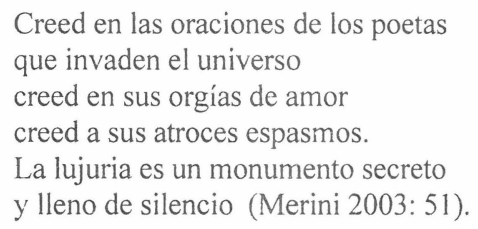

Según Bataille, "es interesante poder demostrar que la actividad sexual, generalmente comparada con la carne comestible (la carne), tiene los mismos privilegios que la poesía" (Bataille 199: 146). En este sentido, la carne ("orgías", "espasmos", "lujuria") se despliega en el terreno de lo pronunciado y lo no pronunciado (mudísima", "jerga", "oraciones", "silencio"), siguiendo el rastro bíblico del "verbo" que se hace "carne". Entre ambos median una serie de elementos anatómicos como "la lengua" y "los labios", dotados de un doble valor simbólico: órganos de contacto físico íntimo, y de trascendencia y ausencia absoluta. La concreción, la materialidad y los límites del cuerpo se convierten, a través del eros-amor, en indistinción, totalidad.

Alda Merini se coloca al otro extremo de Bataille, que identifica la poesía con la eternidad (Bataille 199: 25), cuando dice que "la poesía es el lugar de la nada, el lugar de los encuentros" (Merini 1999: 11). Pero, como todos los extremos se tocan, ambos coinciden en identificar el eros con la muerte.

Por lo tanto el hombre busca su amor como busca ávidamente la muerte (Merini 2000: 24).

Ahora bien, como la noción de eros se define con relación a un cuerpo de mujer, la tradición filosófica identifica esa muerte con lo femenino. Alda Merini, en cambio, hace una inversión de perspectiva, atribuyendo al cuerpo masculino los mismos rasgos que en la tradición caracterizan lo femenino como alteridad. De esta forma la relación eros-amor muta su condición tradicional, deja de ser jerárquica (sujeto y objeto, víctima y verdugo) para convertirse en recíproca.

¿Por qué un hombre o una mujer que nos han defraudado no pueden ser sustituidos rápidamente? ¿Por qué se prefiere ir al manicomio o incluso morir? Quizás porque el hombre, en el amor y también en el goce de cualquier sentido, va buscando desesperadamente la muerte (Merini 1998: 31).

Ahora bien, como señala Umberto Galimberti, hombre y mujer "no son intercambiables" en el eros, que no es sólo una cuestión de contacto, sino un "dispositivo significante" con "significado universal" (Galimberti 2000: 374 y 378). Si en la diferencia sexual está inscrita la ley del significado, cualquier cambio en el significado supone un 
desafío a esa ley. La mayor parte de las ideas filosóficas a cerca del amor-erotismo han sido formuladas casi exclusivamente por varones, y Alda Merini podría colocarse en el campo gravitatorio de filósofos como Lévinas y Bataille, si no fuera porque su experiencia proviene de un "cuerpo de mujer", en el doble sentido biológico-simbólico del término. Como sostienen Luce Irigaray (1994), Judith Butler (1996), Teresa de Lauretis (1999), la concepción misma del eros está profundamente influenciada por la posición de los cuerpos que participan en él, sobre todo cuando el cuerpo femenino abandona su tradicional pasividad.

En el caso de Alda Merini es precisamente la ambigua y simultánea presencia de la mujer objeto/sujeto del amor-eros, el punto interesante y conflictivo de su obra. En su poesía se barajan las imágenes de la mujer que se trasmiten a través de la cultura patriarcal, y que remiten sobre todo a una concepción cristiana, junto con imágenes que se colocan en un orden simbólico diferente, mitológico y pagano, que remiten a figura de la Gran Madre. Las primeras tienden hacia la desmaterialización y descorporización a través de un proceso de fuerte idealización. Las segundas tienden a una encarnación radical, en la que la parte espiritual se materializa no sólo en un cuerpo femenino, sino también en elementos de la naturaleza, entendida como extensión de ese cuerpo. Se trata de imágenes que pueden ser consideradas obscenas, aunque no por la carga de erotismo que puedan encerrar, sino porque el sujeto que las encarna ya no es masculino. Es más, Baudrillard (1980: 34), la llamaría "obscenidad radical" porque el erotismo, el deseo y la sexualidad femenina se hacen visibles en el texto, rompiendo su misterio. Las "diosas obscenas" (Pinkola 2001: 558), forman parte del mito de la Mujer Salvaje, una de las formas metafóricas de la Gran Madre.

El eros vivido y formulado desde un cuerpo de mujer comporta, inevitablemente, una relectura de la masculinidad en función del deseo, la pasión y la imaginación femenina. Cuando la mujer "se escribe a sí misma" afirma una sexualidad independiente de los valores que se imponen socialmente a sus diferentes estatus: "pudor e ignorancia en la virgen, reproducción, educación y fidelidad en la madre y desinterés por el placer y aceptación pasiva de la actividad sexual del hombre en la prostituta" (Galimberti 2000: 429). En toda la obra de Alda Merini encontramos esta "descolocación" de la sexualidad y el deseo con respecto al estado civil, la edad, el lugar o compañero elegido. El eros en femenino rompe la resignación y la discreción a la que las mujeres "están destinadas simbólicamente" (Bourdieu 2000: 47), rompe el circuito vital impuesto a la anatomía femenina y también el círculo de la culpa.

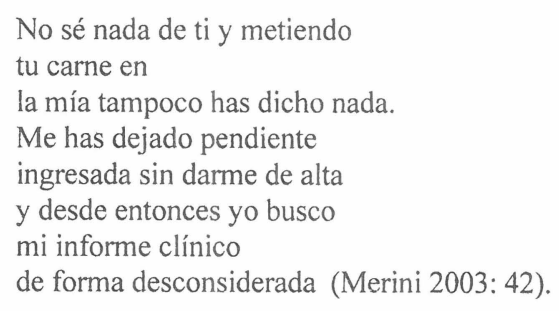

La relectura del eros pone de manifiesto la diferente forma en la que el hombre y la mujer viven la sexualidad, con una mirada de ironía a la sexualidad masculina que se 
orienta sólo y exclusivamente a un acto físico. Alda Merini ridiculiza una sexualidad que se concentra en la "proeza viril", poniéndola en entredicho desde el "otro" punto de vista, donde la proeza no es tal. La actitud jocosa proviene de la naturaleza salvaje de la mujer, donde lo sagrado, lo sexual y lo irreverente se funden.

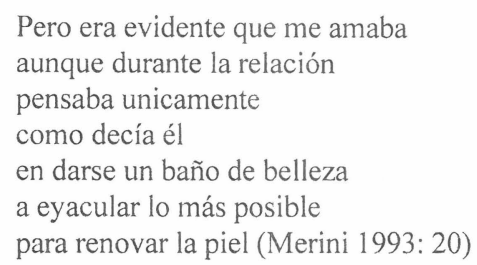

El comportamiento de hombres y mujeres responde, como señala la sociología, a un "habitus de género", es decir, a "un sistema de normas profundamente interiorizadas que, sin expresarse nunca total ni sistemáticamente, rigen la relación de hombres y mujeres con su cuerpo" (Rodríguez 2003: 145). Alda Merini se aleja del habitus corporal femenino, que se caracteriza por sentimientos como pudor o inseguridad, aunque eso suponga su condena.

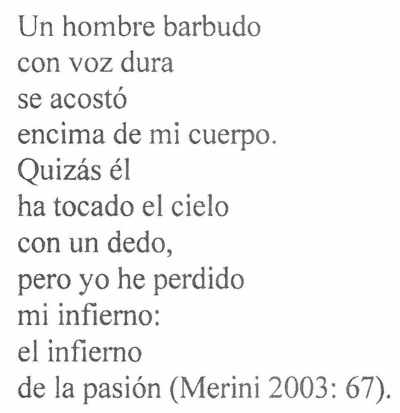

El cuerpo femenino desde una visión masculina, como recuerda Bataille, y como mencionaba Juan Ramón, puede colocarse en la dialéctica del eros, de lo continuo, a través de la belleza, pureza, divinidad pero, al mismo tiempo, puede seguir la dialéctica de la muerte y de la nada, a través de la fealdad, la animalidad, la descomposición. Estas dos tendencias están muy presentes en la poesía de Alda Merini, pero eros y thanatos no son dos conceptos divergentes, sino convergentes. Por ese motivo también el cuerpo masculino objeto de amor, sin llegar a la degradación a la que, en cambio, está sometido el cuerpo femenino, sigue una interesante línea de oscilación: puede desmaterializarse hasta convertirse en un paisaje:

Y después del amor era la paz inmensa

la terraza colorada del Nilo (Merini 2003: 10).

En una huella, en un signo, donde se encierra el anagrama del cuerpo entero:

Aquella percha

que está junto a la pared

y todavía ltiene colgado tu rostro (Merini 2003: 96). 
En un objeto humilde, que se convierte en el símbolo mismo de la relación eróticaamorosa, por su colocación en un espacio determinado de intimidad:

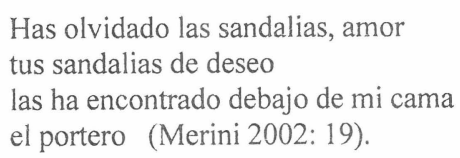

El cuerpo es un "médium", que se trasforma fácilmente en los signos que lo simbolizan, que expresa y traduce sentimientos como el desamor, que a su vez, puede hacerlo desaparecer por completo, como en las metáforas de la "percha" y de las "sandalias", y también de someterlo a un proceso de desmaterialización. En este sentido el cuerpo del hombre "amado", pero que a su vez no ama, que se desvincula de la relación amorosa, presenta una versión caricaturesca, pero sin tintas negras, más bien de cuento de hadas, que lo retrata a través de sus partes menos nobles, como las vísceras, el estómago.

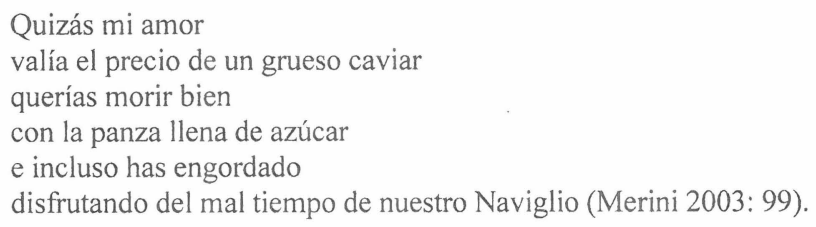

La oscilación que sufre la representación de lo masculino puede estar relacionada con lo que Judith Butler llama "la inestabilidad de las fronteras imaginarias del sexo" (Butler 1996: 81). La misma sexualidad masculina se presenta en términos biológicos casi técnicos ("y eyacular lo más posible/para renovar la piel"), o en términos de absoluta abstracción ("una carne/que tenía hambre de desfallecimientos repentinos", Merini 2003: 15). Mientras que la escena erótica se construye, muchas veces, con la síntesis de los dos:

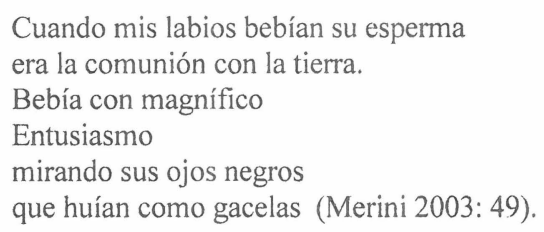

El hombre experimenta un movimiento de salir de sí mismo, que en este caso se recoge en la metáfora de la "huída de las gacelas", del ex-tasis pero, al mismo tiempo, en la mujer se produce un movimiento de "ins-tasis" (Irigaray 1994: 37). La mujer se "apodera" del cuerpo del hombre, en un deseo de "encarnarse en el cuerpo del otro", como dice Sartre (1965: 476). Se apropia del órgano anatómico y simbólico del hombre, de su carne y de "su efecto imaginario" (Butler 1996: 75-76), consiguiendo un doble poder reservado a los hombres: el "poder de hacer disfrutar" (Bourdieu 2000: 34), y el poder simbólico de traducir en palabras, de "representar" un erotismo que no concuerda con la relaciones sociales de dominio. La mujer hace suyo un habitus de comportamiento masculino, es decir, tomar la iniciativa, rompiendo la "subordinación erotizada" (Bourdieu 2000: 35).

La noción de cuerpo femenino que Alda Merini perfila se representa a través de lo grotesco, tanto en su aspecto de metáfora corporal, como en su aspecto de revaloriación de lo marginal. En este sentido, da continuidad a los mitos de la Gran Madre (Neumann 1981), 
y de la Diosa Madre (AA.VV. 1989). El cuerpo de mujer representa en la poesía de Alda Merini el lugar de lo oculto, de lo húmedo, de lo escondido y misterioso, de lo material y de lo oscuro, que se concretan en la figuras simbólicas de la mujer "monstruosa", "anormal": histérica, medusa, hidra, vieja, beduina, maga, salvaje. Lo "grotesco femenino" (Russo 1994), posee al mismo tiempo un carácter subversivo y un proyecto utópico, en los que se afirman nuevas metáforas y nuevas perspectivas desde las que afrontar la realidad.

Muchas de esas metáforas en Alda Merini están ligadas al cuerpo de la mujer: el parto, la maternidad, los hijos, la violación, la virginidad. Incluso la Virgen María, tema central de Magnificat. Un encuentro con María (2002), se presenta como una mujer de colocación incierta, al límite de las leyes del patriarcado. Con respecto a los rígidos esquemas de lo femenino, María logra ser al mismo tiempo virgen y madre, pero también, con respecto a la división cristianismo-paganismo, se coloca entre lo humano y lo divino, al concebir en un cuerpo de carne y hueso el cuerpo de un dios. El tema de la Anunciación, uno de los preferidos de la poeta italiana, aparece muchas veces en una clave que simboliza el encuentro de la mujer con lo sobrenatural y su consiguiente "metamorfosis".

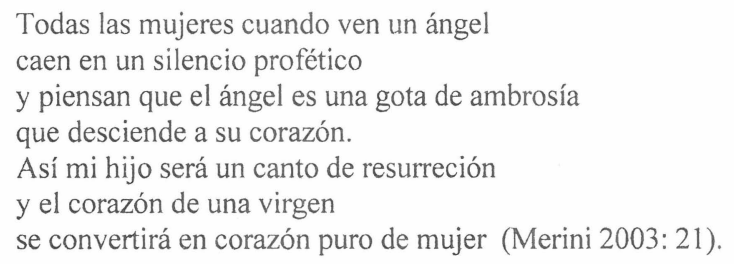

La metáfora del "hijo" se presenta bajo diferentes morfologías, una de ellas es la del amante que se convierte en hijo. De esta forma queda "incorporado", "encarnado" en el cuerpo de la mujer, reflejando la naturaleza social de la imagen del cuerpo, que se construye siempre en relación con la imagen corpórea de un Tú, pero también la "coidentidad" que se crea con el cuerpo con el que nos relacionamos.

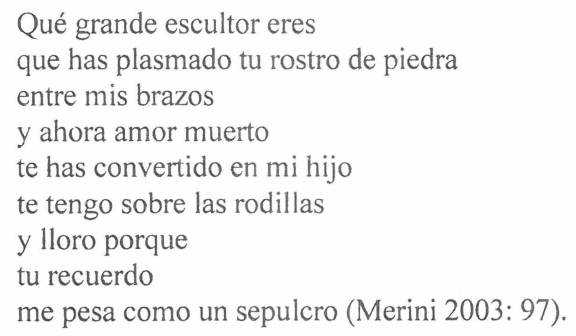

Como puede apreciarse, el cuerpo masculino y femenino participan de muchas de las características del "cuerpo grotesco" bajtiniano (Bachthin 1979). El cuerpo de la mujer es "bicorporal", contiene y crea otro cuerpo. Es un cuerpo no delimitado, en proceso de construcción y de creación, a través del cual se une con otros cuerpos y con el mundo. Este cuerpo "grotesco" recupera de forma existencial para la mujer un modo de relacionarse consigo misma, con los demás y con el mundo que la ideología dominante impide. En este sentido el tema del hijo-amante roza el tabú del incesto, origen y fundamento de las leyes del patriarcado, que arrancan los hijos al dominio de la madre. 


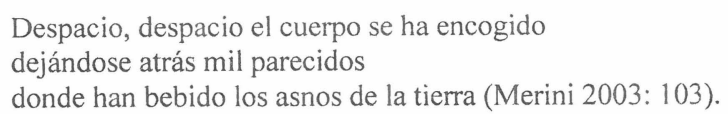

Tanto el "grotesco" como el de la Gran Madre son cuerpos abiertos, expuestos, visitables, cuerpos "ánforas", que contienen el mundo, cuerpos desproporcionados en los que lo interno se hace externo y viceversa, cuerpos-pasadizos donde se funden dimensiones diferentes como lo humano y lo animal, lo animado y lo inerte. Si lo masculino es "la medida de todo" (Bourdieu 2000: 28), lo femenino, por oposición, será lo desmedido, lo insondable, lo inconmisurable, y también, lo tenebroso y amenazador.

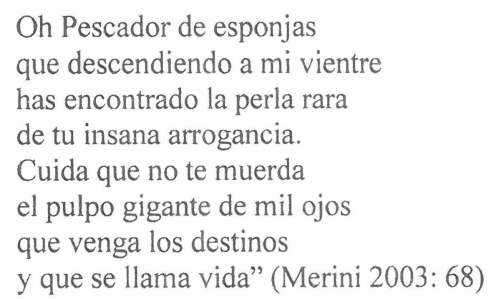

La grandeza de lo femenino estriba en un cuerpo que es "todo vientre", cuerpo cósmico representado, en este caso, por uno de los cuatro elementos esenciales: el agua. Pero esta grandeza esconde un aspecto amenazador. La Gran Madre encarna también diferentes aspectos maléficos, monstruosos ("pulpo gigante", "hidra"), su rostro angelical esconde el de la "maga", ("Soy Diana loca, invencible cazadora". "Mujer rebelde, mujer, quizás maga", Merini 1995: 40), que utiliza su poder destructor contra el hombre, aliándose con las fuerzas naturales y sobrenaturales. De ahí su poder de lanzar conjuros y maldiciones. La amada puede convertirse en "bruja" desairada que reclama su lugar en el amor.

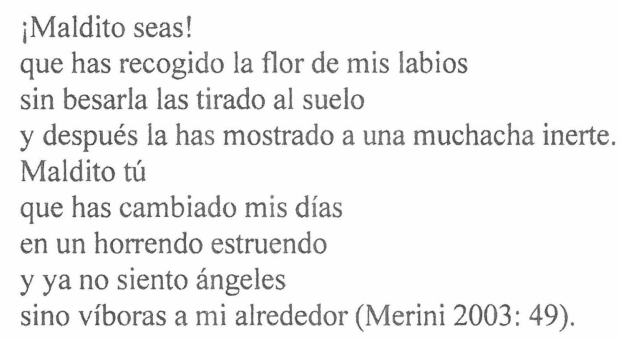

La encarnación del Mal, la tentación, se cifra en un cuerpo de mujer que se define por sí mismo, un cuerpo que busca su placer sin tener en cuenta las normas sociales. Podemos entonces focalizar en sentido etimológico la palabra obs-ceno, que proviene de una raíz hebrea (ob), que significa "maga", "bruja" (Pinkola 2001: 543). La obscena, entonces, está relacionada con el mito de la Mujer Salvaje, que vive al margen de las leyes del patriarcado. La dimensión amenazadora de lo femenino que se esconde tras su aspecto seductor, es que puede perder al amante, corromperlo, desviarlo de su camino hacia la trascendencia. El Mal que encarna la mujer es sobre todo metafísico, trascendental, mientras que el hombre que Alda Merini ama y no le corresponde, no encarna el Mal con mayúsculas, sino, como diría H. Arendt la "banalidad del mal" (Arendt 1992), su cínica 
cotidianidad, hecha de infidelidades y desatenciones ("Me has dejado pendiente/ ingresada sin darme de alta").

En la relectura del eros desde el cuerpo femenino también el hombre puede ocupar el lugar de la "víctima", y del objeto de amor, también puede ser perseguido y, de algún modo, "profanado", en el sentido de implicado en esa relación que se estable con el misterio y lo sagrado.

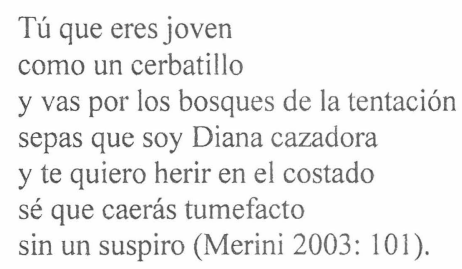

Alda Merini trasfigura míticamente la relación amorosa, aunque en sentido poco convencional en la atribución de papeles: ella, Diana cazadora, él, "joven cerbatillo", porque en la poesía lírica tradicional es "Amor" el que hiere con diferentes armas, pero nunca es el deseo de la mujer el que las empuña.

Postular el eros desde lo simbólico femenino comporta una "descolocación" del cuerpo de la mujer en el imaginario social, y una aparición de imágenes inconsuetas de ese cuerpo, cumpliendo acciones o adoptando posturas excéntricas. Como dice Bourdieu (2000: 43), las posturas del cuerpo de las mujeres, sobre todo las piernas, los brazos y las manos, poseen un significado moral y, por lo tanto, algunos movimientos, o son inmorales, o están fuera del código de comportamiento femenino. "Perseguir" al hombre que se ama es un tema bastante frecuente en la poesía de Alda Merini, una falta de compostura social que se traduce en este poema en una forma defectuosa de caminar.

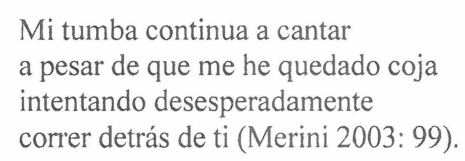

Hay que recordar que el único cuerpo de mujer digno de ser representado en nuestra Cultura es el que responde a ciertos cánones de belleza y, en todo caso, se limita a la mujer joven. La mujer "vieja" está excluida del erotismo y la sexualidad. La mujer vieja, en relación a un cuerpo joven de hombre, es un desafío al "sentido común" que se traduce en un "fuera de lugar", "en una maldición "para siempre":

$$
\begin{aligned}
& \text { Ma han dejado en el pleno de mi ateísmo } \\
& \text { mientras consumaba un rito de amor } \\
& \text { y algo por la espalda } \\
& \text { mientras hacía el amor con un muchacho } \\
& \text { me maldijo para siempre (Merini 2003: 103). }
\end{aligned}
$$

Lo femenino en la seducción es "principio de incertidumbre" (Baudrillard 1980: 22), superficie, reversibilidad, apariencia, y eso permite el juego del cuerpo que se trasforma, asumiendo los rasgos de cualquier fisonomía, al mismo tiempo que se libera de su 
anatomía. Pero la trasformación del cuerpo en Alda Merini va más allá de dicho principio: simboliza la imposibilidad de representarse, la carencia de imágenes con las que identificarse, cuando la mujer sale de los límites de visibilidad, paralelos a los límites del eros que la sociedad impone ("Mujer que no ve los márgenes del amor"). La mujer vieja y atravesada por el desamor trasforma su cuerpo bajo el peso de una indignidad social interiorizada.

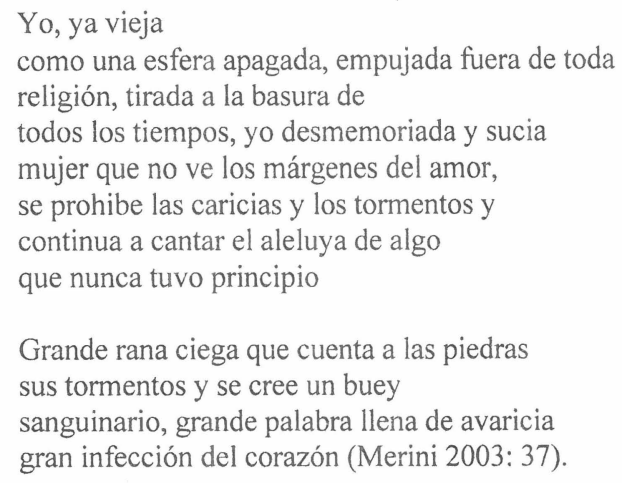

El intento de liberarse de la "carne" esconde un rastro de animalidad ("rana ciega", "buey sanguinario"), y de muerte ("infección"), relacionado con el sacrificio como acto de amor: un cuerpo sin límites no posee un recambio vital, puede sobrevivir sólo devorándose a si mismo. La Gran Madre debe convertirse en víctima para ser "la base del poder sagrado" (Magli 1995: 29). La metáfora de la "rana" sigue la cadena de significantes ("lengua", "labios", "sudor", "vientre") donde lo femenino se identifica con lo húmedo, pero también con lo frío y, en este caso, con lo "inmundo". El buey es uno de los animales que en el sistema mítico-ritual se asocia a la mujer. Aristóteles en su Política lo relaciona con la naturaleza del esclavo y la mujer: el buey es el criado de los pobres, la mujer es el criado de los hombres. Y al mismo tiempo es el animal "sagrado" por excelencia, utilizado para el sacrificio.

Sostiene Bourdieu (2000: 51), que la violencia simbólica se instituye a través de la adhesión de la mujer a las imágenes de percepción y valoración de sí misma que circulan en la cultura, imágenes que la desvalorizan. Esa violencia pasa, en este caso, a formar parte de la propia imagen del yo, que se convierte en "esfera apagada", "tirada a la basura", "desmemoriada", "sucia". Todas ellas imágenes asociadas a la "mujer vieja", a su degradación corporal, objeto de burla en la poesía jocosa tradicional. El proceso de humillación de la propia individualidad pasa, en la segunda estrofa, a identificarse con lo "no humano", en una especie de delirio del yo, pero también en un proceso de "empequeñecimiento" (desde las proporciones del "buey" hasta la "infección"). Bourdieu señala que la feminidad en muchas culturas se resume en el "arte de empequeñecerse" (Bourdieu 2000: 43). Lo monstruoso de la naturaleza ("rana ciega", "buey sanguinario"), es el resultado de un exceso de feminidad, que se identifica con la materia del mundo (Héritier 2000: 143). La alienación en las metáforas zoológicas supone una disolución del yo, que al no poseer un cuerpo es un yo sin historia: el cuerpo de la mujer vieja está "en otra parte": la "vieja" se trasforma y se convierte en un arquetipo mítico. 
La violencia, la amenaza que supone lo femenino, su disolución, abyección y obscenidad nos conducen a lo sagrado y al misticismo. Lo femenino está doblemente consagrado: por la tradición judeocristiana, que idealiza el cuerpo femenino, y por la tradición pagana que considera lo innoble como propio de los dioses. Sólo que las claves de acceso a este doble carácter sagrado son contrarias: la castidad, por un lado y, la sexualidad, por otro. Alda Merini elabora un singular misticismo en el que no hay sublimación a través de la castidad, sino a través del encuentro carnal. En este contexto, la virginidad de lo femenino, lejos de ser una cuestión fisiológica o moral, es una categoría ontológica:

Si la mujer alcanza su propia soledad, se logra tocarla con manos de filigrana, está salvada. El más grande don que pueda recibir una mujer es el milagro de su mente, de su gran locura, de su virginidad (Merini 1994: 45).

Las implicaciones a nivel simbólico son notables: la virginidad deja de plantearse en términos anatómicos, saltando las dicotomías entre cerrada-abierta, que a su vez se corresponden con virginidad-maternidad, y la oposición arriba-abajo, es decir, mentecuerpo. Se trata de una virginidad que nada tiene que ver con "la inocencia", al contrario, es el resultado de un "conocimiento", y por tanto de una elección.

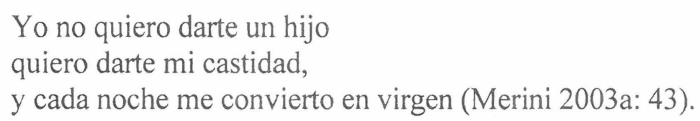

El profundo conflicto que Freud y Foucault ponen de manifiesto entre el cuerpo y la ley, se cifra metafísicamente en la lucha que el cuerpo masculino inscrito en la ley, que "limita el placer, para traducir la actividad lúdica en actividad laboral" (Galimberti 2000: 424), mantiene con el cuerpo femenino que, en cambio, queda fuera de ella.

La mujer es una claridad ulterior, una de esas moleculas tan difusas que se convierten en aire, sabiduría, destino. Si el hombre las pisotea y las injuria es porque no quiere reconocer su sacralidad. Si el hombre las desorienta es porque sabe que conducen al paraíso. Y el hombre prefiere el infierno, el trabajo, el goce (Merini 1994: 45).

La concepción del erotismo en Lévinas o Bataille, presenta un sujeto masculino fragmentado, dividido, pasivo, expuesto, condiciones que definen la naturaleza de lo femenino en todas sus facetas. Por lo tanto, contrariamente al hombre, la mujer sujeto de amor-erotismo, puede recuperar algunas condiciones de lo masculino, mientras que como objeto de erotismo no abandona nunca su estatus, simplemente redunda y ahonda en las condiciones de la disolución de su yo, hasta la anulación total.

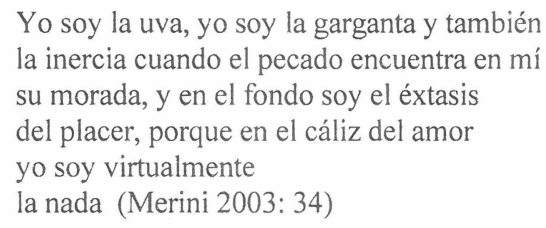

La "nada" representa no sólo la anulación en el otro, donde la "participante femenina del acto erótico aparece como víctima" (Bataille 1991: 19), sino también la falta de 
significación de lo femenino fuera de la maternidad, que constituye, como dice Lévinas, "su auténtica trascendencia ética" (Lévinas 1977). Lo femenino no puede significar sino en función de otros (familia, hijos, marido). Una mujer sola, que ya no es "cuerpo para otros", pierde todo su capital simbólico, y su cuerpo físico se hace invisible a la mirada de los demás, porque no encuentra colocación en la anatomía social.

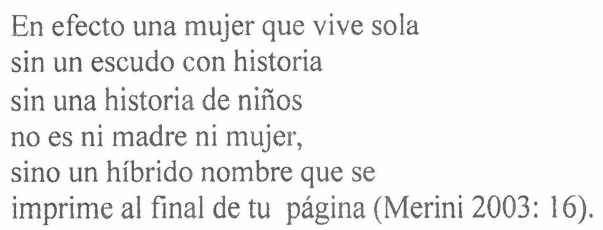

La ausencia de carne en la imagen del "nombre impreso" es una consecuencia directa del desamor, de la disolución de la fuerza del afecto y, sobre todo, de la ausencia de un hombre al que hacer referencia. Como señala Galimberti, "el valor de la mujer no está en su cuerpo, sino en el hombre que en su cuerpo se refleja y refleja el orden de sus relaciones" (Galimberti 2000: 428).

El amor-eros visto desde un cuerpo de mujer recoloca el valor del hombre y, por lo tanto, las relaciones de poder/sumisión que se mantienen con él. La "diseminación", la "dépense", el derroche improductivo del eros, que tanto había horrorizado a filósofos como Platón, Lévinas y Bataille, estigmatizando de paso el cuerpo femenino, encuentra en la obra de Alda Merini un eco y, al mismo tiempo, una recolocación en el cuerpo del hombre. Manifestación de una sensibilidad postmoderna, donde la contradición, en palabras de Remo Bodei, "no constituye un límite, sino un factor de crecimiento" (Bodei 1989: 141), y manifestación de una "escritura mujer" (Cixous 1997), que no se avergüenza de sus potencialidades, que no se autocensura, que utiliza creativamente los elementos del inconsciente colectivo y, al hacerlo, lo transforma.

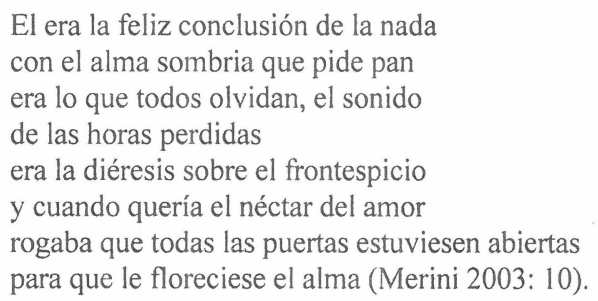

El eros-amor es una relación con una alteridad que excede constantemente el poder y los límites del yo. Pero el "yo" siempre se ha leído en masculino y la "alteridad" siempre se ha concebido en fernenino. La novedad de la poesía de Alda Merini es que plantea una noción de eros-amor en la que derroche estético y trascendencia ética no están reñidos, y además, pueden encarnarse en un cuerpo de hombre.

Si tú no ves el amado, si no te llenas de sus sabores y de las fantasías de amor que en ti genera la persona amada, el alma muere y también el cuerpo para siempre. \{...\} Por lo tanto, el hombre que amas es tu desierto, pero también es tu resurrección (Merini 2000: 64-65). 
En esta nueva imagen de la masculinidad, el hombre representa para la mujer el terreno de su imaginación, pero también su más allá metafísico. Deja de ser el hombre que la define, la coloca y la sustenta en la materialidad física y social, para convertirse en la matería de sus sueños, en su utopía. La "ateridad", que Lévinas cifraba en el rostro de la mujer, se reinscribe en un nuevo orden simbólico, en el que también lo masculino se da en su materialidad inmediata pero, al mismo tiempo, se hace indescifrable en la madeja de los afectos.

Si te mido por tu rostro puedo decir que eres elemental como las piedras. Y como las piedras dulcísimo (Merini 1995: 14)

La representación de lo masculino deja de ser opresiva y deprimente, desde un cuerpo de mujer que es, además, instrumento de conocimiento del mundo, depositario de saberes antiguos y creador de nuevos juegos.

\section{REFERENCIAS BIBLIOGRÁFICAS}

AA.VV, Con Dados de Niebla, marzo-abril, Granada, Diputación de Huelva, 1999.

AA.VV., Le grandi madri, Milán, Feltrinelli, 1989.

ARENDT, H., La banalità del male, Milán, Feltrinelli, 1992.

ARRIAGA FLÓREZ, M., "Cuerpos de mujeres puestos a arder: videojuegos y nuevas formas de arte", Anuario de Investigaciones, volumen XI, Granada, Hésperides, 2003, pp. 409-417.

BACHTIN, M., L'opera di Rabelais e la cultura popolare del Medioevo e del Rinascimento, Turín, Einaudi, 1979.

BARTHES, R., Il piacere del testo, Turín, Einaudi, 1975.

BATAILLE, G., L'erotismo, Milán, Es, 1991.

BAUDRILlARD, J., Della seduzione, Roma, Capelli, 1980.

BODEI, R., "Dialettica, contraddizione e sviluppo nel moderno", en Forme e pensiero del moderno, Milán, Feltrinelli, 1989, pp. 140-155.

BOURDIEU, P., La dominación masculina, Barcelona, Anagrama, 2000.

BUTLER, J., Corpi che contano. I limiti discorsivi del "sesso", Milán, Feltrinelli, 1996.

CIXOUS, H., "Il riso della Medusa", en Critiche femministe e teorie letterarie, Bolonia, Clueb, 1997, pp. 221-246.

DE LAURETIS, T., Soggetti eccentrici, Milán, Feltrinelli, 1999.

FOUCAUlT, M., El uso de los placeres. historia de la sexualidad, Madrid, Siglo XXI, 1987.

GALIMBERTI, U. et alii, L'immaginario sessuale, Milán, Bompiani, 1995. 
GALIMBERTi, U., Il corpo, Milán, Feltrinelli, 2002.

HERITIER, F., Maschile e femminile. Il pensiero della differenza, Bari-Roma, Laterza, 2000.

IRIGARAY, L., Essere due, Milán, Bollati Boringhieri, 1994.

JIMÉNEZ, J. R., Estética y ética estética, Francisco Garfias ed., Madrid, Aguilar, 1967.

KRISTEVA, J., Lo femenino y lo sagrado, Madrid, Cátedra, 2000.

LEVINAS, E., Il tempo e l'altro, Génova, Il Melangolo, 1977.

MAGLI, I., De la dignidad de la mujer, Barcelona, Icaria, 1995.

MERINI, A., Titano amori intorno, Milán, La Vita Felice, 1993.

MERINI, A., Reato di vita, Milán, Melusine, 1994.

MERINI, A., Ballate non pagate, Turín, Einaudi, 1995.

MERINI, A., La pazza della porta accanto, Milán, Bompiani, 1995a.

MERINI, A., Lettere a un racconto, Milán, Rizzoli, 1998.

MERINI, A., La poesia luogo del nulla, Lecce, Manni, 1999.

MERINI, A., L'anima innamorata, Milán, Frassinelli, 2000.

MERINI, A., Parole d'amore. un incontro con Gesù, Milán, Frassinelli, 2001.

MERINI, A., Folle, folle, folle di amore per te, Milán, Salani, 2002.

MERINI, A., Magnificat. un incontro con Maria, Milán, Frassinelli, 2002a.

MERINI, A., Clinica dell'abbandono, Turín, Einaudi, 2003.

MERINI, A., La carne degli angeli, Milán, Frassinelli, 2003a.

MURARO, L., L'ordine simbolico della madre, Roma, Editori Riuniti, 1991.

NAVARro, M. (ed.), Para comprender el cuerpo de la mujer. Una perspectiva bíblica y ética, Estella, Evd, 1996.

NEUMANN, E., La grande madre, Roma, Astrolabio, 1981.

PANDOLFI, M. (ed.), Perché il corpo. Utopia, sofferenza, desiderio, Roma, Meltemi, 1996.

PINKOLA ESTÉS, C., Mujeres que corren con los lobos, Madrid, Suma de Letras, 2001.

RODRÍGUEZ MENÉNDEZ, M. C., La configuración del género en los procesos de socialización, Oviedo, Krk, 2003.

RUSSO, M., The Female Grotesque. Risk, Excess and Modernity, Routledge, New York and London, 1994.

SARTRE, J. P., L'essere e il nulla, Milán, Il Saggiatore, 1965. 
"La lujuria es un monumento secreto": cuerpos y eros en Alda Merini

SISSA, G., "L'atto del desiderio", en Perché il corpo. utopia, sofferenza, desiderio, Roma, Meltemi, 1996, pp. 99-120.

STAMPA, G., Rime, Milán, Rizzoli, 1954. 
